УДК $372.811 .111(004)$

DOI https://doi.org/10.52726/as.pedagogy/2021.3.2.28

\author{
В. І. ПАВЛЮК \\ кандидат педагогічних наук, доцент, \\ дочент кафедри іноземних мов, \\ Уманський державний педагогічний університет імені Павла Тичини, \\ м. Умань, Черкаська область, Украӥна \\ Електронна пошта: vika.pavlyuk.83@gmail.com \\ https://orcid.org/0000-0002-9612-2218
}

\title{
ЦИФРОВІ ПЛАТФОРМИ ДЛЯ СТВОРЕННЯ СТОРІТЕЛІНГУ НА УРОКАХ АНГЛІЙСЬКОЇ МОВИ У ПОЧАТКОВІЙ ШКОЛІ
}

Сторітелінг як інструмент навчання заохочує молодших школярів до виразного читання та допомагає їм передавати свої думки та почуття чітко й зрозуміло, що є необхідним для опанування навичок повсякденного життя. Крім того, сторітелінг запускає механізм критичного мислення.

У статті розглядається метод сторітелінгу як ефективний дидактичний ресурс у викладанні англійської мови у початковій школі. Розкривається сутність поняття «сторітелінг» та «цифровий сторітелінг», підкреслюється значення навчання англійської мови за допомогою методу сторітелінгу для формування мовленнєвої компетенції учнів початкової школи. Основна увага зосереджується на можливостях цифрових платформ на заняттях з англійської мови молодших школярів закладів середньої освіти. Досліджено можливості використання навчальних платформ у навчальному процесі молодших школярів, виокремлені переваги використання методу сторітелінгу та рекомендації щодо планування й проведення сторітелінгу для молодших школярів. Залучення цифрових технологій до навчальної діяльності в початковій школі відкриває нові можливості у навчанні іноземних мов у початковій школі. Зокрема, цифровий сторітелінг є ефективним методом для розвитку комунікативних навичок молодших школярів, оскільки такі види діяльності на занятті з англійської мови, як аудіювання історії, запис ії елементів, відтворення чужої історії, навчають важливих мовленнєних навичок загалом.

Метою статті є заохочення вчителів англійської мови до вдосконалення викладання англійської мови за інноваційними методиками навчання іноземних мов, зокрема і за допомогою цифрового сторітелінгу як методологічного ресурсу. У перспективі реалізація інших конкретних цілей для впровадження сторітелінга в навчальний план, покращення мотивації учнів до вивчення іноземних мов, розвиток критичного мислення учнів та творчого сприйняття за допомогою ігрових ситуацій, створення позитивної навчальної атмосфери у вивченні англійської мови тощо.

Ключові слова: сторітелінг, цифровий сторітелінг, молодші школярі, початкова школа, мовленнєва компетентність.

Постановка проблеми. Сторітелінг як навчальна технологія для молодших школярів грунтується на вмінні красномовно говорити, здатності учителя правильно створювати художні образи, а учня - представляти їх в своїй уяві, що водночас не потребує спеціального обладнання. Як інструмент навчання сторітелінг заохочує молодших школярів до виразного читання та допомагає їм передавати свої думки та почуття чітко й зрозуміло, що є необхідним для опанування навичок повсякденного життя. Крім того, сторітелінг запускає механізм критичного мислення.

Сторітеліенг та інсценізація історії мають ряд особливостей, які роблять їх природними для інтеграції під час уроків. Обидва види діяльності грунтуються на вродженій здатності дітей до розвитку своєї фантазії та здатності до уявної гри. За допомогою історій та їх інсценізації діти розвивають розуміння себе в навколишньому світі і природу речей, досліджують важливі питання їх повсякденного життя. Оскільки персонажі та події історій не є реальними, то інсценізація історії не напружує дітей психологічно, а навпаки - допомагає розрядити будь-яку неприємну ситуацію в історії більш приємним способом.

Аналіз попередніх досліджень. Сторітелінгом як методом роботи на уроках у початковій школі в різний час цікавилися як вітчизняні (Л. Панченко, М. Рудіна, О. Шванова, М. Гич, С. Машкіна), так і зарубіжні науковці (Б. Робін, Н. Свіні-Бьорт, В. Херріот, С. Мартін, Р. Бенмейор, С. Агіляр, Х. Аркантара, К. Штраус, T. Банішевський). Однак використання методу сторітелінгу саме на уроках англійської мови 
у початковій школі не було достатньо розглянуто вітчизняними науковцями в їхніх працях. Саме тому вбачаємо за необхідне розкрити особливості введення сторітелінгу на заняттях англійської мови в початковій школі закладів середньої освіти України.

Як стверджують В. Гарріот і С. Мартін, мовленнєва практика за допомогою сторітелінгу сприяє розвитку навичок мовлення та усного спілкування, пов'язаних з вимовою та артикуляцією [Harriot, Martin: 7].

К. Штраус зазначає, що крім розвитку лінгвістичних здібностей в початковій освіті, є багато інших переваг сторітелінгу - комунікативних, соціальних, афективних та когнітивних [Straus: 10].

С. Агіляр та X. Алькантара переконані, що для молодших школярів найкращою формою сторітелінгу є казка, адже казкові історії є знайомою та доступною формою обміну інформацією, іншими словами, вони можуть оживити абстрактні концепції, надавши їм конкретної форми. Будь-яку інформацію, представлену у цій формі розповіді, легше зберегти, ніж випадковий список непов'язаних та поодиноких фактів. Дитина запам'ятовує казку найкраще, оскільки озвучені події з використанням емоційного складника роблять ії більш пам'ятною [Aguilar Alcántara : 7].

Згідно із С. Агіляр та Х. Алькантара, сторітелінг - це м'який та ефективний спосіб вироблення позитивного ставлення до навчання, оскільки для дитини це мотивація та задоволення [Aguilar Alcántara: 7].

В епоху цифрових технологій педагоги мають можливість скористатися технічними засобами навчання для сторітелінгу. В останні десятиліття з'явилося поняття «цифрове оповідання».

Б. Робін стверджує, що цифрове оповідання - це спосіб розповідати та презентувати історії за допомогою цифрових носіїв, включаючи графіку, звук та музику. Зазвичай його використовують для посилання на короткі особисті розповіді, створені за допомогою широкодоступних недорогих цифрових медіатехнологій [Robin : 9].

Р. Бенмейор вбачає у цифровому сторітелінгу педагогіку, засновану на діяльності, у якій студенти можуть висунути на перший план свої знання та досвід у галузі культури, щоб змінити своє мислення та розширити свої можливості [Benmayor : 6].

Етапи впровадження цифрового оповідання за Т. Банашевським (2005) передбачають: логістику та планування, створення сценаріїв, викладання елементів ефективного цифрового оповідання, управління технологією та оцінювання. Водночас дослідник пропонує три сфери навичок, які слід розглядати під час навчання елементам цифрового оповідання: 1. домен історії, що робить історію цифровою, 2. Візуальна / медійна область - звернення до навичок візуальної грамотності та 3. технічна сфера вирішення необхідних технічних навичок для побудови цифрової історії [Banaszewksi : 5].

Серед вітчизняних науковців, які у своїх працях висвітлюють питання цифрового сторітелінгу, слід виділити Л. Панченко, яка запровадила авторський спецкурс «Цифровий сторітелінг в освіті дорослих» для системи підвищення кваліфікації педагогічних працівників, мета якого - розглянути та обговорити можливості цифрового сторітелінгу як нового напряму розвитку освітніх ресурсів, визначити його складники та найбільш популярні засоби для освітян, обговорити проблеми співтворчості педагога й учня на основі сторітелінгу, а також надати слухачам особистого досвіду проєктування власних історій за допомогою сучасних цифрових сервісів [Панченко : 10].

Вітчизняні дослідники також у своїх працях висвітлюють питання впровадження сторітелінгу на уроках. М. Гич стверджує, що сторітелінг - це трансляція історій зі «змістом». Під такою «історією» розуміється будь-яка сюжетно пов'язана розповідь, яка $є$ виразом думки людини щодо подій історії.

С. Машкіна зазначає, що сторітелінг відіграє велику роль у навчанні усного мовлення, лексики, граматики та аудіювання в англійській мові. Головною характерною ознакою цього методу є вільний вибір змісту повідомлення, засобів для його створення, що зумовлені особистими інтересами учня. Дослідниця переконана, що використання методу сторітелінгу розвиває вміння учнів працювати в групах, аналізувати текст, виділяти основні події і шукати їх причини, узагальнювати і робити висновки. Основна мета методу - стимулювати творчу уяву і розвивати критичне мислення дітей, що 
відповідає головному завданню Нової Української Школи [Машкіна: 2].

Виклад основного матеріалу. Попри те, що підготовка до проведення сторітелінгу у початковій школі вимагає від вчителя ретельного планування, цей метод роботи на уроках англійської мови є цікавим для обох сторін процесу - учнів та учителя, і змістовному навчанню та високому рівню мотивації. Виділяють такі переваги використання методу сторітелінгу:

- викликає почуття благополуччя i розслаблення;

- підвищує готовність дітей передавати думки та почуття оточуючим;

- заохочує до активної участі на занятті;

- підвищує рівень мовленнєвої компетентності;

- заохочує до використання уяви та творчості;

- заохочує до співпраці між учнями;

- розвиває вміння слухати. [2].

Існують різні можливі підходи до використання історій на уроці англійської мови. Вони варіюються від періодичного використання оповідань тематичного характеру до використання додаткових історій на основі навчальної програми.

С. Агіляр та X. Алькантара зазначають, що вчителям необхідно дотримуватися певних рекомендацій для планування і проведення сторітелінгу для молодших школярів.

По-перше, необхідно ознайомити учнів зі змістом, мовою та поняттями, які містить історія, за допомогою малюнків, тематичного словникового запасу тощо.

По-друге, у діяльність під час розповіді важливо залучити учнів шляхом передбачення того, як продовжиться історія. Однак основна мета на цьому етапі, на думку дослідниці, посилити розуміння сюжету історії.

По-третє, провести роботу на закріплення, створення кінцевого продукту (рольова гра, перетворення історії на гру, творчість). Для цього учителеві необхідно перевірити послідовність розповіді за допомогою дій, підвести підсумки змісту історії та задавати запитання на розуміння [Aguilar Alcántara : 7].

Водночас М. Гич стверджує: «Для ефективного проведення сторітелінгу на уроці вчитель має дотриматися таких правил, як:
- правильний добір історії;

- розуміння того, навіщо іiі взагалі розповідати;

- добір ефектного початку розповіді;

- логічне вибудовування розповіді;

- урахування аудиторії слухачів, яким розповідається історія;

- прийоми для формування зацікавленості історією слухача;

- уміння висловити своє ставлення до розповіді» [Гич : 1].

Дослідниця також рекомендує вчителю дотримуватися таких методичних порад у процесі сторітелінгу: сторітелер має «відчувати» аудиторію; розповідь має бути для обраного кола слухачів, з урахуванням їх вікових, соціальних та освітніх особливостей; історія має мати ідею, яку слід зробити очевидною для слухачів; у вигаданій історії має прослідковуватися авторська позиція, сторітелер має висловити своє особисте ставлення до оповідання так, щоб це вплинуло на слухачів; у цій історії має бути такий яскравий художній образ, щоб він запам'ятовувався слухачам мимоволі; обов'язково повинен бути персонаж (людина, істота, установа, предмет; історія повинна мати фабулу та головного персонажа [Гич : 1].

Наразі популярним $є$ цифровий сторітелінг у навчанні молодших школярів іноземним мовам. Зокрема, Л. Панченко пропонує вчителям та методистам 3 англійської мови, користуючись рядом цифрових інструментів, на кшталт вільного інструменту My StoryMaker, який дозволяє створити просту історію у вигляді дитячої книжки шляхом обирання головного персонажу, його мети та тих об'єктів, які він хоче знайти, отримати тощо [1].

Для роботи 3 цифровим сторітелінгом важливо провести з учнями мозковий штурм істоpiï, а саме: донести повідомлення, яке сторітелер хоче передати, задати загальні запитання щодо можливого змісту історії (Які персонажі будуть задіяні? Яким буде сюжет? Що буде відбуватися?). Важливо також визначитися із елементами розповіді, наочністю, використанням ТЗН, джерела історії, видами створення образів (за допомогою зображення, звуку, руху тощо), написати сценарій сторітелінгу і об'єднати його 3 елементами цифрового медіа, визначитися 3 темпом мовлення та продуктом відтворення 
історії учнями (усна розповідь, малюнок, власний електронний формат історії тощо).

Сучасні діти цікавляться такими типами цифрових оповідань, як вебщоденники блогерів, вебсеріали та фотожурнали. Зокрема, на заняттях $з$ англійської мови $з$ молодшими школярами, доцільно виділити онлайн-платформи для створення власних історій My Storybook («Моя книга історій») та ZooBurst.

В усьому світі платформа My Storybook використовується вчителями початкової школи для навчання цифрової грамотності та розвитку навичок читання й письма. Для роботи із молодшими школярами на My Storybook необхідно провести інтегроване заняття 3 англійської мови з елементами інформатики.

Для початку роботи учні повинні мати створені адреси електронної пошти, за цієї умови вони можуть зареєструватися та почати користуватися платформою My Storybook. Платформа дозволяє учням писати текст власної історії, додавати додаткові сторінки до книги, оформлювати історію картинками, представленими у безкоштовних шаблонах. По закінченні історії iii можна опублікувати та поділитися посиланням зі своїм класом. Існує можливість вивести історію на екран і прогортати їі як презентацію 3 коментарями. Навіть якщо учні не мають адрес електронної пошти, або батьки ще не дозволяють їм їх створювати, можливо заходити до платформи 3 однією адресою електронної пошти, наприклад, вчителя. Можна створювати безліч історій, і вони відображатимуться у бібліотеці вчителя в розділі «Мої книги».

Платформа MyStorybook.com $є$ безкоштовною для створення і подальшого використання історій. Недоліком платформи $€$ стягнення плати за скачування історій у PDF-файлах для їх друку, однак кількість переваг платформи, наприклад, оновлення шаблонів, участь у конкурсах на написання історій, поетапний інструктаж та поради щодо створення історій, розвиток навичок грамотності дитини тощо, робить останню важливим і необхідним інстру- ментом у навчанні молодших школярів англійської мови на уроках сторітелінгу.

ZooBurst $\epsilon$ альтернативною цифровою платформою для створення оповідання англійською мовою, який дозволить створити власну книжку 3D pop-up. ZooBurst дозволяе юним письменникам використовувати більше ніж10 000 безкоштовних зображень та інших матеріалів у наявній базі даних. Користувачі ZooBurst можуть ділитися своїми книгами між собою, використовуючи гіперпосилання або розміщуючи їх у будь-якому блозі і на сайті. Pecypc ZooBurst Basic на $€$ повністю безкоштовним, інші ресурси на платформі (ZooBurst Premium, ZooBurst School License) є платними для використання додаткових функцій.

Висновки. Сторітелінг як дидактичний ресурс, який використовується у навчанні іноземної мови для створення природного контексту та позитивної атмосфери для навчання, сприяє розвитку базових мовних навичок молодшого школяра.

У століття цифрових технологій важливо залучати дітей до читання за допомогою можливостей мережі Інтернет. Залучення цифрових технологій до навчальної діяльності в початковій школі відкриває нові можливості у навчанні іноземних мов у початковій школі. Зокрема, цифровий сторітелінг $\epsilon$ ефективним методом для розвитку комунікативних навичок молодших школярів, оскільки такі види діяльності на занятті з англійської мови, як аудіювання історії, запис іiі елементів, відтворення чужої історії, навчають важливих мовленнєних навичок загалом. Вчителям англійської мови необхідно частіше звертатися до методу сторітелінгу для розвитку вищеозначених навичок у своїх учнів, навчитися користуватися технічними засобами для створення історій разом 3 дітьми та впроваджувати елементи навчання сторітелінгу в наявну навчальну програму з іноземної мови. Надалі школярі можуть використовувати цю навчальну технологію для отримання іншого досвіду, створювати та ділитися власними розповідями за допомогою різних цифрових засобів.

\section{ЛІТЕРАТУРА}

1. Гич М. Сторітелінг як інноваційна методика формування мовної компетентності учнів ЗНЗ. Науковий вісник МНУ імені В. О. Сухомлинського. Педагогічні науки № 4 (51), грудень 2015. С 188-190.

2. Машкіна С. А. Використання методів «фішбоун» та «сторітелінг» на уроках у початковій школі на прикладі вивчення теми: «закріплення літери ії. Опрацювання тексту «Гроші України» Теорія $і$ методика навчання: проблеми та пошуки. Збірник наукових праць. Випуск 14. С. 86-92. 
3. Рудіна М., Шванова О. Технологія сторітелінгу в системі формування фахової компетентності майбутніх перекладачів. Гуманітарна освіта в технічних вищих навчальних закладах. № 38, Київ, 2018. С 26-30.

4. Aguilar S., Alcántara J. (2017) Storytelling as a tool for Science teaching in bilingual primary education. X congreso internacional sobre investigación en didáctica de las ciencias Extraordinario, pp. 5085-5090.

5. Banaszewksi T. (2005) Digital storytelling: supporting digital literacy in grades 4-12. (PhD Thesis), Georgia Institute of Technology.

6. Benmayor, R. (2008) Digital Storytelling as a Signature Pedagogy for the New Humanities. Arts and Humanities in Higher Education, Vol. 7, pp. 119-130.

7. Harriott, W. A., Martin, S. S. (2004) Using Culturally Responsive Activities to Promote Social Competence and Classroom Community. Teaching Exceptional Children. Vol. 37 (1), pp. 48-54.

8. Panchenko L. (2008) Digital storytelling: co-creation of teacher and student, Metodyst, no. 6(78), pp. 34-38, 2018. (in Ukrainian) Libraries Unlimited.

9. Robin, B. R. (2008) Digital Storytelling: A Powerful Technology Tool for the 21 st Century Classroom. Theory Into Practice. Vol. 47(3), pp. 220-228

10. Strauss, K. (2006) Tales with Tails: Storytelling the Wonders of the Natural World. Westport, Connecticut. 248 p.

11. Sweeney-Burt, N. (2014) Implementing Digital Storytelling as a Technology Integration Approach with Primary School Children. Irish Journal of Academic Practice. Vol. 3: Iss. 1, Article 4. doi:10.21427/D7DT6G .

\section{ДЖЕРЕЛА}

1. MyStorybook.com веб-сайт. Електронна адреса статті: https://www.mystorybook.com (дата відвідування сайту:28 серпня 2021).

2. Teaching English. Електронна адреса статті: https://www.teachingenglish.org.uk/article/storytelling-benefitstips) (дата відвідування сайту:28 серпня 2021).

3. ZooBurst. Електронна адреса статті:: https://zooburst-ios.soft112.com/ (дата відвідування сайту:28 серпня 2021).

\section{REFERENCES}

1. Hych M. (2015) Storitelinh yak innovatsiina metodyka formuvannia movnoi kompetentnosti uchniv ZNZ. Naukovyi visnyk MNU imeni V. O. Sukhomlynskoho. Pedahohichni nauky, no 4 (51), pp. 188-190.

2. Mashkina S. A. Vykorystannia metodiv «fishboun» ta «storitelinh» na urokakh u pochatkovii shkoli na prykladi vyvchennia temy: «zakriplennia litery yii. Opratsiuvannia tekstu "Hroshi Ukrainy". Proceedings of the Teoriia i metodyka navchannia: problemy ta poshuky. Vol. 14, pp. 86-92.

3. Rudina M., Shvanova O. (2018) Tekhnolohiia storitelinhu v systemi formuvannia fakhovoi kompetentnosti maibutnikh perekladachiv. Humanitarna osvita v tekhnichnykh vyshchykh navchalnykh zakladakh. no. 38, pp. 26-30.

4. Aguilar S., Alcántara J. (2017) Storytelling as a tool for Science teaching in bilingual primary education. $\mathrm{X}$ congreso internacional sobre investigación en didáctica de las ciencias Extraordinario, pp. 5085-5090.

5. Banaszewksi T. (2005) Digital storytelling: supporting digital literacy in grades 4-12. (PhD Thesis), Georgia Institute of Technology.

6. Benmayor, R. (2008) Digital Storytelling as a Signature Pedagogy for the New Humanities. Arts and Humanities in Higher Education, Vol. 7, pp. 119-130.

7. Harriott, W. A., Martin, S. S. (2004) Using Culturally Responsive Activities to Promote Social Competence and Classroom Community. Teaching Exceptional Children. Vol. 37 (1), pp. 48-54.

8. Panchenko L. (2008) Digital storytelling: co-creation of teacher and student, Metodyst, no. 6(78), pp. 34-38, 2018. (in Ukrainian) Libraries Unlimited.

9. Robin, B. R. (2008) Digital Storytelling: A Powerful Technology Tool for the 21 st Century Classroom. Theory Into Practice. Vol. 47(3), pp. 220-228

10. Strauss, K. (2006) Tales with Tails: Storytelling the Wonders of the Natural World. Westport, Connecticut. 248 p.

11. Sweeney-Burt, N. (2014) Implementing Digital Storytelling as a Technology Integration Approach with Primary School Children. Irish Journal of Academic Practice. Vol. 3: Iss. 1, Article 4. doi:10.21427/D7DT6G .

\section{SOURCES}

1. MyStorybook.com веб-сайт. Retrieved from: https://www.mystorybook.com accessed:28 August 2021).

2. Teaching English. Retrieved from: https://www.teachingenglish.org.uk/article/storytelling-benefits-tips) (accessed:28 August 2021).

3. ZooBurst Retrieved from: https://zooburst-ios.soft112.com/ (accessed:28 August 2021). 


\section{I. PAVLYUK}

Candidate of Pedagogical Sciences, Associate Professor, Associate Professor at the Department of Foreign Languages, Pavlo Tychyna Uman State Pedagogical University,

Uman, Cherkasy region, Ukraine

E-mail:vika.pavlyuk.83@gmail.com

https://orcid.org/0000-0002-9612-2218

\section{DIGITAL PLATFORMS FOR CREATING STORETELING ON ENGLISH LANGUAGE LESSONS AT PRIMARY SCHOOL}

Storytelling, as a learning tool, encourages younger students to read aloud and helps them to communicate their thoughts and feelings clearly, which is necessary for mastering the skills of everyday life. In addition, storytelling triggers a mechanism of critical thinking.

The article considers the method of storytelling as an effective didactic resource in teaching English in primary school. The essence of the concept of "storytelling" and "digital storytelling" is revealed, the importance of teaching English with the help of the storytelling method for the formation of speech competence of primary school students is emphasized. The main focus is on the capabilities of digital platforms in English classes for younger school students. Possibilities of using educational platforms in the educational process of younger schoolchildren are investigated, the advantages of using the storytelling method and recommendations on planning and conducting storytelling for younger schoolchildren are highlighted. Involvement of digital technologies in educational activities in primary school opens new opportunities in teaching foreign languages in primary school. In particular, digital storytelling is an effective method for developing the communication skills of primary school children, as such activities in English as listening to a story, recording its elements, reproducing another's stories, teach important speech skills in general.

The aim of the article is to encourage English teachers to improve the teaching of English by innovative methods of teaching foreign languages, including through digital storytelling as a methodological resource. In the future, the implementation of other specific goals for the introduction of storytelling in the curriculum, improving students' motivation to learn foreign languages, developing students' critical thinking and creative perception through game situations, creating a positive learning atmosphere in learning English, etc.

Key words: storytelling, digital storytelling, younger schoolchildren, primary school, language competence. 